\title{
Distribution and antifungal susceptibility of Candida species in patients with increased risk for fungal infections
}

\author{
Gordana Mirchevska*, Maja Jurhar Pavlova, Vesna Kotevska, Elena Trajkovska-Dokic, \\ Zaklina Cekovska, Gordana Jankoska, Milena Petrovska, Nikola Panovski
}

Institute of Microbiology and Parasitology, Faculty of Medicine, University "Ss. Cyril and Methodius", Str. 50 Divizija No.6, 1000, Skopje, Republic of Macedonia

Received: August 2016; Accepted: October 2016

\begin{abstract}
Candida species are opportunistic yeasts that can be a serious threat for immunocompromised and critically ill patients, and a cause for increased morbidity and mortality in hospitalized patients. The aim of this study was to determine the frequency and distribution of different Candida species in clinical specimens in patients with increased risk for fungal infections, and to determine the antifungal susceptibility profile of invasive Candida species to antifungal agents. During a two year period, clinical specimens from 120 patients divided into 4 groups were analysed at the Institute of microbiology and parasitology, Faculty of Medicine, Skopje, Republic of Macedonia. Each of these 4 groups consisted of specimens from 30 patients, with primary immune deficiency, critically ill patients treated in the intensive care units (ICU), patients with mucosal candidiasis only, and patients with cystic fibrosis. All specimens were investigated with conventional mycological methods. Identification of Candida species was performed with VITEK-2 system (bioMérieux, France). E-test strips of fluconazole, voriconazole, amphotericin B and caspofungin (AB bioMerieux, France) were used for determination of the antifungal susceptibility profile. In this study, a total of 115 isolates of Candida species were confirmed in different clinical specimens (91 isolates from mucosal surfaces and 24 isolates from blood culture). Colonisation of mucosal membranes of gastrointestinal, respiratory and/or urinary tracts was registered in $56.67 \%$ (17/30), 56.67\% (17/30), 90\% (27/30) and 100\% (30/30) of the specimens in the first, second, third and fourth group respectively. In all four groups of patients, the following Candida species were confirmed: C. albicans - 55\%, C. glabrata - 17.6\%, C. parapsilosis $-7.7 \%$, C. tropicalis $-6.6 \%$, unidentified Candida species $-4.4 \%$, C. dubliniensis $-3.3 \%$, C. kefyr - $2.2 \%$, and one isolate of C. rugosa, C. pelliculosa and C. krusei each. Positive blood culture was registered in $23.33 \%$ specimens from the first group, $43.33 \%$ in the second group, $23.08 \%$ of the third group, and in one specimen of the fourth group. The most frequent isolates from blood culture were C. tropicalis and C. krusei, followed by C. albicans, C. parapsilosis and C. tropicalis, and in the second group C. albicans and C. pelliculosa were equally distributed, followed by $C$. parapsilosis and C. glabrata. All invasive isolates of Candida species were susceptible to amphotericin B, voriconazole and caspofungin. Resistance to fluconazole was registered in $8.3 \%$ (2/24) of all confirmed Candida species. Dose-dependent susceptibility to fluconazole was confirmed in $46 \%(11 / 24)$ of the isolates. Our study confirms high prevalence of colonisation and candidemia with non-albicans Candida species. Resistance to antifungal agents was registered only in two isolates of $C$. $k r u-$ sei. An epidemiological study is necessary for surveillance of dynamics of candidemia and antifungal susceptibility profile of invasive isolates of Candida species in our patients.
\end{abstract}

Key words: Candida species, antifungals, fungal infections, E-test

\section{Introduction}

The incidence of fungal infections due to Candida species is dramatically increased in the recent few decades
(Ben-Ami et al., 2009; Girmenia et al., 2011), and is directly associated with increased morbidity and mortality, especially in critically ill patients (Morgan et al., 2005; Zaoutis et al., 2005). These microbes are responsible for $9-12 \%$ of all septicaemias, and are ranked on the fourth position in

\footnotetext{
* gordmir@yahoo.com
} 
many studies across USA (Wisplinghoff et al., 2004) and on the sixth or seventh position as causes of nosocomial septicaemias in many European studies (Marchetti et al., 2004). Candida-associated septicaemias frequently develop in intensive care units (ICU), and they are responsible for 33$55 \%$ of all septicaemias (Luzzati et al., 2005; Wisplinghoff et al., 2004). Almirante et al. (2005) have shown an incidence of 4.3/100,000 inhabitants in Spain, and in Iceland, an increase from 4.3 to 5.7 cases on 100,000 population. In an Australian study for nosocomial septicaemias, Candida speciesis ranked on the fourth place $(15.5 \%)$, and according to Meyer et al. (2013) and Prowle et al. (2011) the incidence of the primary nosocomial candidemia in 682 German ICU centres remained stable during a 5-year period. In a recent study from Italy, a total of 105 episodes of candidemia developed during an 18-month period, with 16.5 cases per 1000 hospital beds (Montagna et al., 2013). In a big prospective, multicentric study in ICUs in France, fungi were identified in $3.2 \%$ of patients with microbiologically documented infections (Quenot et al., 2013). Candidemia in ICU were associated with significant increase of hospital costs and length of hospital stay (Ben-Ami et al., 2004). Prolonged stay in ICU, prematurity, broad spectrum antibiotics, prolonged use of corticosteroids, chemotherapy and radiotherapy, intravascular catheters and parenteral nutrition, pronounced immunosuppression and mucous membranes disruption, and HIV/AIDS are among the most prominent predisposing factors for development of invasive fungal infections.

Candida species are among the most frequent etiological agents of invasive fungal infections. Among these, $C$. albicans has been the main cause of invasive candidiasis. However, during the last two to three decades, an overall increase of candidemias caused by non-albicans Candidas pecies has been registered. In parallel to the increased incidence of invasive candidiasis, the ARTEMIS DISK international program for surveillance of candidemias registers an increase of the incidence of non-albicans Candida species in a 6-years period (Pfaller et al., 2010). C. glabrata, C. tropicalis, C. krusei and C. parapsilosis are the most frequently encountered species (Girmenia et al., 2011; Morgan et al., 2005). These non-albicans Candida species usually demonstrate lower susceptibility to antifungal agents (polyenes and azoles) which are used in treatment of serious fungal infections (Zaoutis et al., 2005; Wisplinghoff et al., 2004). This shift in the spectrum is explained with increased prophylactic use of fluconazole from the end of 1980s, which has been widely used for prophylaxis and treatment in immunocompromised patients, which resulted in decrease of overall incidence of invasive mycoses, but increase in incidence of invasive infections with non-albicans Candida species.

The aim of this study was to determine the frequency of different Candida species in clinical specimens, in patients with primary immune deficiency, critically ill patients treated in intensive care units, patients with mucous candidiasis and cystic fibrosis patients, to determine the distribution of different Candida species in each group, and to determine the antifungal susceptibility profile of invasive Candida species towards the most frequently used antifungal agents.

\section{Material and methods}

\section{Study design}

A prospective diagnostic study was performed at the Institute for microbiology and parasitology, Medical faculty in Skopje, during a 2-years period, from March 2012 until May 2014.

\section{Groups of patients and investigations}

In this study, specimens from the mucosal surfaces of gastrointestinal, respiratory and urinary tract (mouth swab, throat swab, sputum, tracheal aspirate, stool, urine), and primarily sterile specimens (BAL, blood) from 120 patients classified in 4 different groups according to the clinical diagnosis and risk factors for invasive candidiasis (group I patients with primary immune deficiency, HIV/AIDS, neutropenia, haematological diseases; group II - patients with prolonged hospital stay in ICU receiving combined antibacterial treatment with broad spectrum antibiotics, group III - patients with mucosal candidiasis and group IV - cystic fibrosis patients) using the EORTC/MSG criteria (European organization for research and treatment of cancer/ mycoses study group). The specimens were investigated with conventional mycological methods (Gram stain and culture on special media for fungal growth support). They were inoculated on Sabouraud and chromogenic CALB medium (Oxoid). Blood cultures were analysed using the automated BacT/ALERT system (bioMérieux, France). Identification of Candida species was performed with biochemical analysis with automated computerised VITEK-2 system (bioMérieux, France). E-test strips of fluconazole $(0.016-256 \mu \mathrm{g} / \mathrm{ml})$, voriconazole $(0.002-32 \mu \mathrm{g} / \mathrm{ml})$, amphotericin B $(0.002-32 \mu \mathrm{g} / \mathrm{ml})$ and caspofungin $(0.004$ - $32 \mu \mathrm{g} / \mathrm{ml}$ ) (AB bioMerieux, France) were used for determination of antifungal susceptibility profile of the invasive isolates of Candida species. Reference ATCC strains for the quality control of the antifungal susceptibility testing were used: C. albicans ATCC 90028, C. parapsilosis ATCC 22019, C. krusei ATCC 6258. RPMI 1640 (Roswell Park Memorial Institute) (RPG, Remel) medium (150 mm) enriched with $2 \%$ glucose and buffered with MOPS buffer (3-(N-morpholino) propanesulfonic acid) were used for antifungal susceptibility testing of susceptibility profile of Candida species with E-test (Mirchevska, 2011). 


\section{Results}

Specimens from 120 patients participated in this study, which were classified in 4 groups: group I $(n=30)$ - patients with primary immune deficiency (HIV/ADIS, neutropenia, haematological diseases), group II $(\mathrm{n}=30)$ - patients with prolonged hospital stay in ICU receiving combined antibacterial treatment with broad spectrum antibiotics, group III $(\mathrm{n}=30)$ - patients with mucosal candidiasis and group IV $(\mathrm{n}=30)$ - cystic fibrosis patients. Their characteristics in respect to age and gender as well as the number of patients per each group are presented in Table 1 .

According to the gender structure of the participants, men were more frequently identified in groups I, III and IV $(60 \%, 56.67 \%, 53.33 \%$ respectively), and women in the group II (56.67\%). The average age of patients with primary immune deficiency was $39.13 \pm 21.8$ years, $65.63 \pm 29.8$ for the patients in the second group, $51.91 \pm 18.4$ in the third group and $16.23 \pm 6.4$ years in the fourth group (Table 1).

In Table 2, distribution of the examined participants in all four groups, according to clinical diagnosis for proven, probable and possible fungal infection, with EORTC/MSG
(European organization for research and treatment of cancer/mycoses study group) criteria are presented.

According to these criteria, most frequently, a proven invasive fungal infection was registered in patients with prolonged parenteral broad spectrum antibiotic treatment (56.67\%), followed by patients with primary immune deficiency (33.33\%), in 3 patients with mucosal candidiasis and only in one patient with cystic fibrosis. Differences in distribution of proven, probable and possible fungal infection were statistically significant between group I versus groups III and IV, and between group II versus groups III and IV.

In cultures from gastrointestinal tract (GIT), urinary tract (UT) and respiratory tract (RT) specimens, colonisation was registered in $56.67 \%$ specimens from the first and second group, $90 \%$ specimens from the third group, and in all 30 specimens from the fourth group (Table 3). Differences between the group with primary immune deficiency and prolonged parenteral broad spectrum antibiotic treatment versus groups with mucosal candidiasis and cystic fibrosis patients were statistically significant.

Table 1. Characteristics of patients according to age and gender

\begin{tabular}{|c|c|c|c|c|c|}
\hline \multirow[t]{2}{*}{ Variable } & \multicolumn{5}{|c|}{ Group of patients } \\
\hline & $\begin{array}{c}\text { group I } \\
\mathrm{n}=30(\%)\end{array}$ & $\begin{array}{c}\text { group II } \\
\mathrm{n}=30(\%)\end{array}$ & $\begin{array}{c}\text { group II } \\
\mathrm{n}=30(\%)\end{array}$ & $\begin{array}{c}\text { group II } \\
\mathrm{n}=30(\%)\end{array}$ & $\begin{array}{c}\text { Total } \\
\mathrm{n}=120(\%)\end{array}$ \\
\hline \multicolumn{6}{|l|}{ Gender } \\
\hline women & $12(40 \%)$ & $17(56.67 \%)$ & $13(43.33 \%)$ & $14(46.67 \%)$ & $56(46.7 \%)$ \\
\hline men & $18(60 \%)$ & $13(43.33 \%)$ & $17(56.67 \%)$ & $16(53.33 \%)$ & $64(53.33 \%)$ \\
\hline \multicolumn{6}{|l|}{ Age } \\
\hline $\begin{array}{l}\text { Years }(\text { mean } \pm \text { SD) } \\
\text { min-max }\end{array}$ & $\begin{array}{c}39.13 \pm 21.8 \\
3-68\end{array}$ & $\begin{array}{l}65.63 \pm 29.8 \\
21-83\end{array}$ & $\begin{array}{l}51.91 \pm 18.4 \\
18-93\end{array}$ & $\begin{array}{c}16.23 \pm 6.4 \\
7-30\end{array}$ & $\begin{array}{c}43.0 \pm 24.1 \\
3-82\end{array}$ \\
\hline${ }^{\mathrm{a}} \mathrm{p}=0.6$ & & & & & \\
\hline
\end{tabular}

Table 2. Characteristics of patients according to EORTC/MSG criteria

\begin{tabular}{|c|c|c|c|c|c|}
\hline \multirow[t]{2}{*}{ Variable } & \multicolumn{5}{|c|}{ Group of patients } \\
\hline & $\begin{array}{c}\text { group I } \\
\mathrm{n}=30(\%)\end{array}$ & $\begin{array}{c}\text { group II } \\
\mathrm{n}=30(\%)\end{array}$ & $\begin{array}{c}\text { group II } \\
\mathrm{n}=30(\%)\end{array}$ & $\begin{array}{c}\text { group II } \\
\mathrm{n}=30(\%)\end{array}$ & $\begin{array}{c}\text { Total } \\
\mathrm{n}=120(\%)\end{array}$ \\
\hline \multicolumn{6}{|c|}{ Classification } \\
\hline proven & $10(33.33 \%)$ & $17(56.67 \%)$ & 0 & $1(3.33 \%)$ & $28(23.33 \%)$ \\
\hline probable & $12(40 \%)$ & $11(36.67 \%)$ & $6(20 \%)$ & $8(26.67 \%)$ & $37(30.83 \%)$ \\
\hline \multirow[t]{3}{*}{ possible } & $8(26.67 \%)$ & $2(6.67 \%)$ & $24(80 \%)$ & $21(70 \%)$ & $55(45.83 \%)$ \\
\hline & \multicolumn{5}{|c|}{ Chi-square: $54.08{ }^{\mathrm{a}} \mathrm{p}<0.001$} \\
\hline & $\begin{array}{l}\text { I vs II } \mathrm{ns} \\
\text { I vs III } \mathrm{p}<0.001 \\
\text { I vs IV } \mathrm{p}<0.0009^{*}\end{array}$ & $\begin{array}{l}\text { II vs III } p \\
\text { II vs IV } p\end{array}$ & & IV ns & \\
\hline
\end{tabular}


Table 3. Characteristics of patients according to confirmed colonisation on mucosal surfaces

\begin{tabular}{|c|c|c|c|c|c|}
\hline \multirow[t]{2}{*}{ Variable } & \multicolumn{5}{|c|}{ Group of patients } \\
\hline & $\begin{array}{c}\text { group I } \\
\mathrm{n}=30(\%)\end{array}$ & $\begin{array}{c}\text { group II } \\
\mathrm{n}=30(\%)\end{array}$ & $\begin{array}{c}\text { group II } \\
\mathrm{n}=30(\%)\end{array}$ & $\begin{array}{c}\text { group II } \\
\mathrm{n}=30(\%)\end{array}$ & $\begin{array}{c}\text { Total } \\
\mathrm{n}=120(\%)\end{array}$ \\
\hline \multicolumn{6}{|c|}{ Colonisation } \\
\hline no & $13(43.33 \%)$ & $13(43.33 \%)$ & $3(10 \%)$ & 0 & $29(24.17 \%)$ \\
\hline yes & $17(56.67 \%)$ & $17(56.67 \%)$ & $27(90 \%)$ & $30(100 \%)$ & $91(75.83 \%)$ \\
\hline & \multicolumn{5}{|c|}{$\begin{array}{l}\text { Chi-square: } 24.8 p=0.000016^{* *} \\
\text { I and II vs III } p=0.003^{* *} \\
\text { I and II vs IV } p=0.00017^{* *}\end{array}$} \\
\hline
\end{tabular}

Table 4. Characteristics of patients according to confirmed colonisation in GIT, RT and UT specimens

\begin{tabular}{lccccc}
\hline \hline Colonization - sites & $\begin{array}{c}\text { group I } \\
(\mathrm{n}=30)\end{array}$ & $\begin{array}{c}\text { group II } \\
(\mathrm{n}=30)\end{array}$ & $\begin{array}{c}\text { group III } \\
(\mathrm{n}=30)\end{array}$ & $\begin{array}{c}\text { group IV } \\
(\mathrm{n}=30)\end{array}$ & $\begin{array}{c}\text { Total } \\
(\mathrm{n}=120)\end{array}$ \\
\hline Mouth, sputum, rectal swab & 2 & 0 & 0 & 0 & 2 \\
Mouth, BAL, stool & 1 & 0 & 0 & 0 & 1 \\
Mouth, BAL & 1 & 0 & 0 & 0 & 1 \\
Mouth & 2 & 0 & 0 & 0 & 2 \\
Sputum, stool & 1 & 0 & 0 & 0 & 1 \\
Stool & 1 & 0 & 0 & 0 & 1 \\
Mouth, stool & 1 & 0 & 0 & 0 & 1 \\
Mouth, sputum, stool & 3 & 0 & 0 & 0 & 3 \\
Mouth, sputum & 3 & 2 & 0 & 0 & 5 \\
Stool, sputum & 1 & 0 & 0 & 0 & 1 \\
Urine & 1 & 6 & 14 & 0 & 21 \\
BAL & 0 & 2 & 0 & 0 & 2 \\
Mouth, sputum, skin & 0 & 1 & 0 & 0 & 1 \\
Tracheal aspirate & 0 & 2 & 0 & 0 & 2 \\
Mouth, stool, tracheal aspirate & 0 & 1 & 0 & 0 & 1 \\
Stool, tracheal aspirate & 0 & 2 & 0 & 0 & 2 \\
Wound swab, rectal swab & 0 & 1 & 0 & 0 & 1 \\
Culture from esophageal mucosa biopsy material & 0 & 0 & 13 & 0 & 13 \\
Sputum & 0 & 0 & 0 & 29 & 29 \\
Bronchial aspirate & 0 & 0 & 0 & 1 & 1 \\
Total & 17 & 17 & 27 & 30 & 91 \\
\hline & & & & & \\
\hline
\end{tabular}

In Table 4 are presented localizations in the analysed groups, from where Candida species was isolated.

In Table 5 are presented yeast species isolated from colonized surfaces from GIT, RT and UT in all analysed groups of patients.

The total number of isolated yeasts from primarily nonsterile and colonized sites with normal flora was 91 strains.
From these, C. albicans - 55\% (50/91) was most frequently isolated species, followed by C. glabrata-17.6\% (16/91), C. parapsilosis - 7.7\% (7/91), C. tropicalis $-6.6 \%(6 / 91)$, unidentified $C$. species-4.4\% (4/91), C. dubliniensis $-3.3 \%$ (3/91), C. kefyr-2.2\% (2/91), and one isolate each of C. rugosa, C. pelliculosa and C. krusei. C. albicans, C. glabrata, C. parapsilosis and C. tropicalis accounted for $86.9 \%$ 
Table 5. Candida species isolated from colonized mucosal surfaces from GIT, RT and UT

\begin{tabular}{|c|c|c|c|c|c|}
\hline Variable & $\begin{array}{l}\text { group I } \\
(\mathrm{n}=30)\end{array}$ & $\begin{array}{l}\text { group II } \\
(\mathrm{n}=30)\end{array}$ & $\begin{array}{c}\text { group III } \\
(\mathrm{n}=30)\end{array}$ & $\begin{array}{c}\text { group IV } \\
(\mathrm{n}=30)\end{array}$ & $\begin{array}{c}\text { Total } \\
(\mathrm{n}=120)\end{array}$ \\
\hline \multicolumn{6}{|l|}{ Yeast species on colonised sites } \\
\hline C. dubliniensis & 1 & 0 & 0 & 2 & 3 \\
\hline C. albicans and C. tropicalis & 2 & 0 & 0 & 0 & 2 \\
\hline C. albicans & 7 & 7 & 18 & 5 & 37 \\
\hline C. tropicalis & 4 & 0 & 0 & 0 & 4 \\
\hline C. glabrata & 2 & 3 & 8 & 1 & 14 \\
\hline C. parapsilosis & 0 & 4 & 1 & 1 & 6 \\
\hline C. species & 1 & 3 & 0 & 0 & 4 \\
\hline C. albicans and P. aeruginosa & 0 & 0 & 0 & 6 & 6 \\
\hline C. rugosa & 0 & 0 & 0 & 1 & 1 \\
\hline C. tropicalis and MRSA & 0 & 0 & 0 & 1 & 1 \\
\hline C. albicans and B. cepacia & 0 & 0 & 0 & 1 & 1 \\
\hline C. kefyr and P. aeruginosa & 0 & 0 & 0 & 1 & 1 \\
\hline C. pelliculosa and $P$. aeruginosa & 0 & 0 & 0 & 1 & 1 \\
\hline C. albicans and MRSA & 0 & 0 & 0 & 4 & 4 \\
\hline C. glabrata and $P$. aeruginosa & 0 & 0 & 0 & 1 & 1 \\
\hline C. krusei and H. influenzae & 0 & 0 & 0 & 1 & 1 \\
\hline C. albicans and Flavobacterium & 0 & 0 & 0 & 1 & 1 \\
\hline C. glabrata and S. maltophilia & 0 & 0 & 0 & 1 & 1 \\
\hline C. kefyr & 0 & 0 & 0 & 1 & 1 \\
\hline C. parapsilosis and S. maltophilia & 0 & 0 & 0 & 1 & 1 \\
\hline Total & 17 & 17 & 27 & 30 & 91 \\
\hline
\end{tabular}

from the total isolated yeasts from the sites colonized with normal flora. C. albicans was most frequently isolated from sputum, followed by mouth swab, urine and stool. $C$. glabrata was most frequently confirmed in urine, followed by sputum and mouth swab. C. parapsilosis was also most often isolated from urine and sputum, followed by mouth swab and skin. C. tropicalis was most frequently isolated from mouth swab, followed by sputum and stool. C. dubliniensis was isolated from mouth swab, sputum and rectal swab. Regarding the specimens, sputum was the most frequent specimen in which yeasts were identified, especially in ICU patients, followed by urine and mouth swab, stool, skin and tracheal aspirate. The most frequent coloniser in the group of patients with primary immune deficiency was C. albicans, followed by C. tropicalis and C. glabra$t a$. In specimens from patients of the second group, $C$. albicans was again the most frequent coloniser, followed by C. parapsilosis and C. glabrata. In the third group, in patients with mucosal candidiasis, in biopsy specimens from GIT was confirmed C. albicans, followed by C. glabrata. In patients with cystic fibrosis, the most frequent coloniser of the respiratory mucosa was C. albicans, followed by

\section{C. dubliniensis.}

In Table 6 are presented the yeast species confirmed in blood from all examined patients.

The blood culture analysis showed that in $23.33 \%$ specimens in the group I, $43.33 \%$ in the group II, $23.08 \%$ specimens from the third group and one specimen in the group IV respectively, the blood culture was positive. The statistical analysis confirmed that positive blood culture was significantly less frequent finding in patients with cystic fibrosis, compared to the group of patients with primary immune deficiency $(p=0.023)$, and patients with prolonged ICU stay and prolonged antibiotic treatment $(p=0.00025)$. The most frequent isolates from blood culture in the group of patients with primary immune deficiency were $C$. tropicalis and C. krusei, followed by C. albicans and C. parapsilosis, and in the group of patients with prolonged ICU stay and prolonged antibiotic treatment C. albicans and C. pelliculosa were equally presented, followed by $C$. parapsilosis and C. glabrata. Antifungal susceptibility testing of invasive isolates was performed with E-test to four systemic antifungal agents. This method allows determination of MIC breakpoint values of antifungal agents, which catego- 
Table 6. Yeast species isolated from blood culture

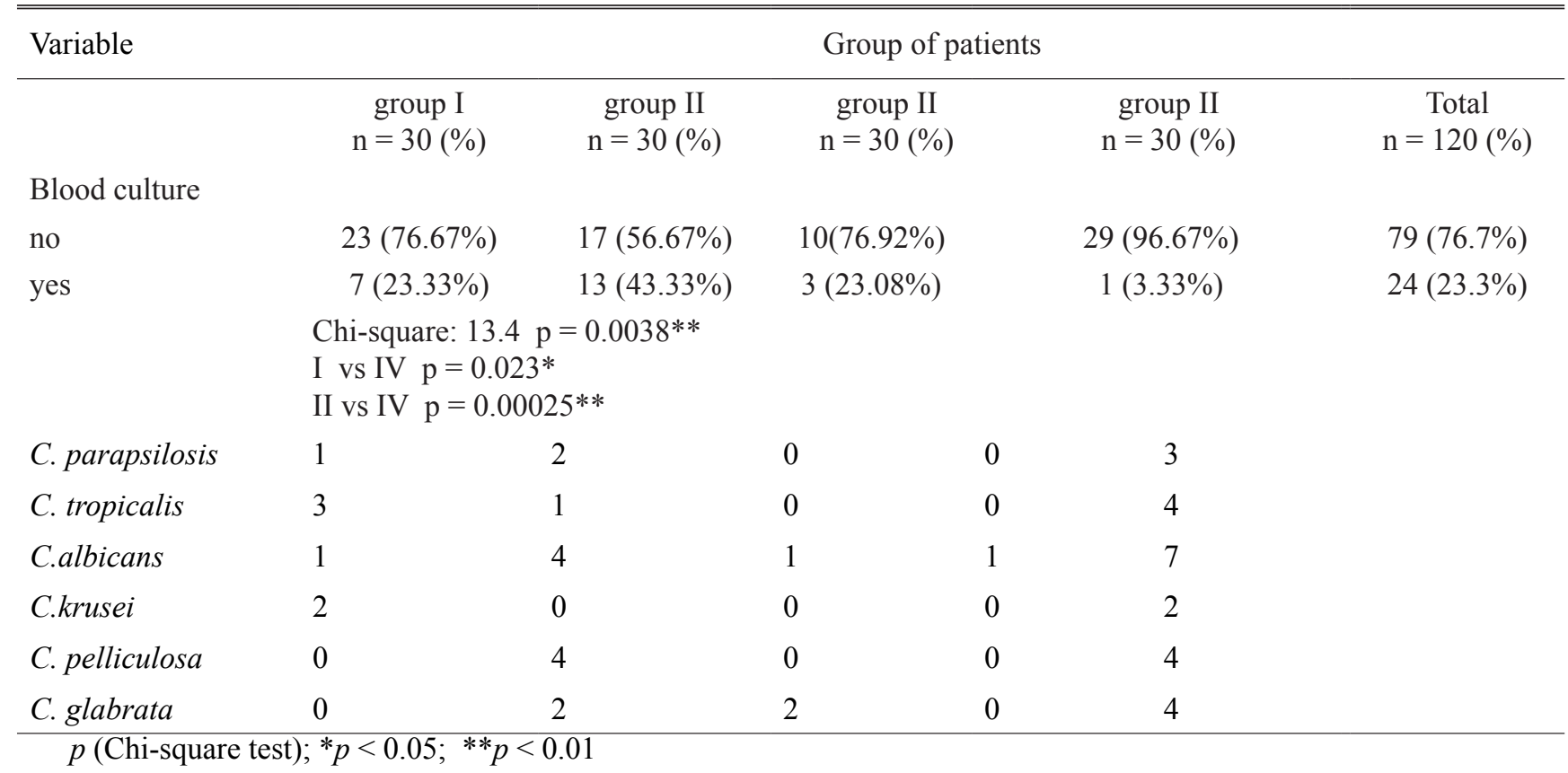

rize yeasts in the following categories: S-susceptible, I-intermediate, S-DD-susceptible dose-dependent, and R-resistant. Table 7 and Fig. 1 present the range of MIC values of amphotericin B for Candida species determined with E-test, according to the species. On the $\mathrm{X}$ axis are presented the minimal inhibitory concentrations (MICs) of the antifungal agents, and the $\mathrm{Y}$ axis present the number of isolates of Candida species showing different MICs to the examined antifungal agents. The minimal inhibitory concentrations of amphotericin B against the examined yeasts, determined with E-test was in the range $0.25-1.0 \mu \mathrm{g} / \mathrm{ml}$. Inhibition of the growth of $20(83.3 \%)$ isolates was achieved with MIC of amphotericin B of $\leq 0.5 \mu \mathrm{g} / \mathrm{ml}$. The highest MIC value that was registered among $17 \%$ (4/24) isolates of Candida species was $1.0 \mu \mathrm{g} / \mathrm{ml}$.

Table 7. Range of MIC values of amphotericin B for different Candida spp. determined with E-test.

\section{Species}

Number of isolates (24) MIC $(\mu \mathrm{g} / \mathrm{ml}) \min .-\max$.

\begin{tabular}{ll}
\hline C.albicans (7) & $0.25-0.5$ \\
C.glabrata (4) & $0.25-0.5$ \\
C.tropicalis (4) & $0.5-1.0$ \\
C.pelliculosa (4) & 0.5 \\
C.parapsilosis (3) & $0.25-0.5$ \\
C.krusei (2) & $0.5-1.0$ \\
\hline
\end{tabular}

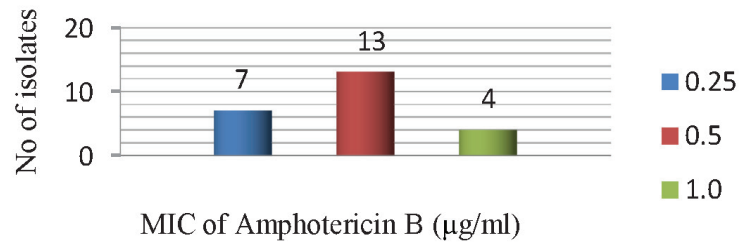

Fig.1. MIC values of amphotericin B determined with Etest $(\mu \mathrm{g} / \mathrm{ml})$

Table 8 and Fig. 2 present the range of MIC values of fluconazole for Candida species determined with Etest. The minimal inhibitory concentrations of fluconazole towards the examined yeasts, determined with the E-test were in the range $0.5-\geq 128 \mu \mathrm{g} / \mathrm{ml}$. The inhibition of the growth of $2(8.3 \%), 9(38 \%)$ and $11(46 \%)$ were achieved with MIC values of fluconazole $0.5,<4$ and $16-32 \mu \mathrm{g} /$ $\mathrm{ml}$ respectively. The highest MIC registered among $8.3 \%$ $(2 / 24)$ strains of Candida species was $\geq 128 \mu \mathrm{g} / \mathrm{ml}$. 
Table 8. Range of MIC values of fluconazole for different Candida spp. determined with E-test

\begin{tabular}{ll}
\hline \hline $\begin{array}{l}\text { Species } \\
\text { Number of isolates }(24)\end{array}$ & $\mathrm{MIC}(\mu \mathrm{g} / \mathrm{ml}) \mathrm{min} .-\mathrm{max}$. \\
\hline C.albicans (7) & $0.5-32.0$ \\
C.glabrata (4) & $4.0-16.0$ \\
C.tropicalis (4) & $4.0-16.0$ \\
C.pelliculosa (4) & $16.0-32.0$ \\
C.parapsilosis (3) & $0.75-1.0$ \\
C.krusei (2) & $\geq 128$ \\
\hline
\end{tabular}

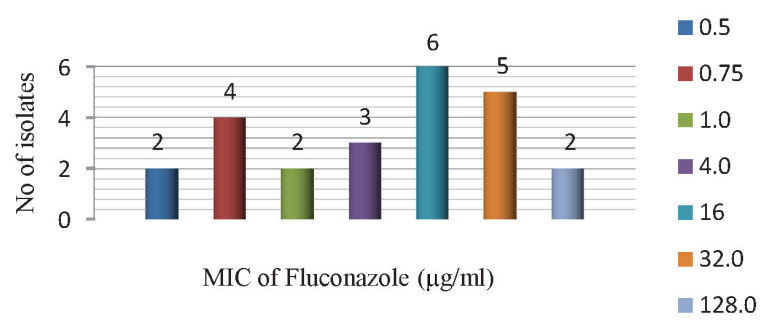

Fig.2. MIC values of fluconazole determined with E-test $(\mu \mathrm{g} / \mathrm{ml})$.

Table 9 and Fig. 3 present the range of MIC values of voriconazole for Candida species determined with E-test. The minimal inhibitory concentrations of voriconazole towards the examined yeasts, determined with the E-test was in range $0.06-0.5 \mu \mathrm{g} / \mathrm{ml}$. Inhibition of growth in $15(63 \%)$ isolates were achieved with MIC of voriconazole of 0.125 $\mu \mathrm{g} / \mathrm{ml}$. The highest MIC registered among 25\% (6/24) of Candida species was $0.5 \mu \mathrm{g} / \mathrm{ml}$.

Table 9. Range of MIC values of voriconazole for different Candida spp determined with E-test

\begin{tabular}{ll}
\hline \hline $\begin{array}{l}\text { Species } \\
\text { Number of isolates (24) }\end{array}$ & $\mathrm{MIC}(\mu \mathrm{g} / \mathrm{ml}) \mathrm{min} .-\max$. \\
\hline C.albicans (7) & $0.06-0.125$ \\
C.glabrata (4) & 0.5 \\
C.tropicalis (4) & $0.06-0.125$ \\
C.pelliculosa (4) & $0.125-0.5$ \\
C.parapsilosis (3) & 0.125 \\
C.krusei (2) & 0.5 \\
\hline
\end{tabular}

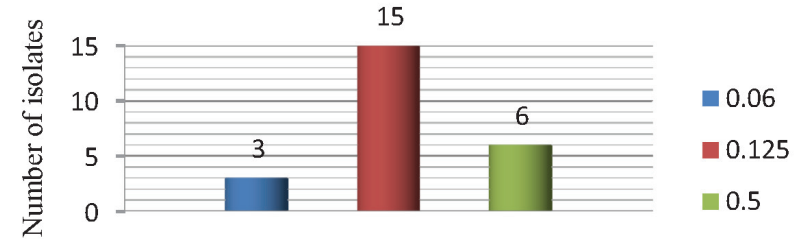

MIC of Voriconazole $(\mu \mathrm{g} / \mathrm{ml})$

Fig.3. MIC values of voriconazole determined with Etest $(\mu \mathrm{g} / \mathrm{ml})$.

Table 10 and Fig. 4 present the range of MIC values of caspofungin for Candida species determined with Etest. The minimal inhibitory concentration of caspofungin towards the examined yeasts, determined with the E-test, was in range $0.064-0.5 \mu \mathrm{g} / \mathrm{ml}$. Inhibition of growth in 6 $(25 \%)$ isolates was achieved with the highest MIC of caspofungin $(0.5 \mu \mathrm{g} / \mathrm{ml})$.

Table 10. Range of MIC values of caspofungin for different Candida spp. determined with E-test

\begin{tabular}{ll}
\hline \hline $\begin{array}{l}\text { Species } \\
\text { Number of isolates (24) }\end{array}$ & $\mathrm{MIC}(\mu \mathrm{g} / \mathrm{ml}) \mathrm{min} .-\mathrm{max}$. \\
\hline C.albicans (7) & $0.064-0.25$ \\
C.glabrata (4) & $0.25-0.5$ \\
C.tropicalis (4) & $0.125-0.25$ \\
C.pelliculosa (4) & $0.25-0.5$ \\
C.parapsilosis (3) & $0.25-0.5$ \\
C.krusei (2) & 0.25 \\
\hline
\end{tabular}

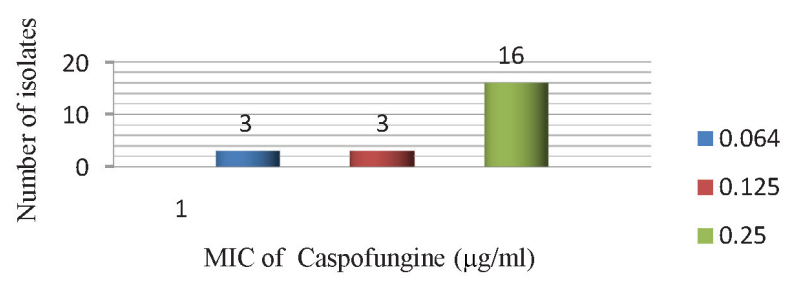

Fig.4. MIC values of caspofungin determined with Etest $(\mu \mathrm{g} / \mathrm{ml})$.

In Table 11 are presented all invasive isolates of Candida species from blood culture, classified according to antifungal susceptibility profile (fluconazole, voriconazole, amphotericin B and caspofungin), determined through de- 
Table 11. Susceptibility profile of invasive isolates of Candida species to amphotericin B, fluconazole, voriconazole and caspofungin

\begin{tabular}{|c|c|c|c|c|c|c|c|c|c|}
\hline \multirow{2}{*}{$\begin{array}{c}\text { Species } \\
\text { No. of isolates }\end{array}$} & \multicolumn{2}{|c|}{ Amphotericin B } & \multicolumn{3}{|c|}{ Fluconazole } & \multicolumn{2}{|c|}{ Voriconazole } & \multicolumn{2}{|c|}{ Caspofungin } \\
\hline & $\mathrm{S}$ & $\mathrm{R}$ & $\mathrm{S}$ & $\mathrm{R}$ & S-DD & $\mathrm{S}$ & S-DD & $\mathrm{S}$ & $\mathrm{R}$ \\
\hline C.albicans (7) & 7 & 0 & 5 & 0 & 2 & 7 & 0 & 7 & 0 \\
\hline C.tropicalis (4) & 4 & 0 & 1 & 0 & 3 & 4 & 0 & 4 & 0 \\
\hline C.glabrata (4) & 4 & 0 & 2 & 0 & 2 & 4 & 0 & 4 & 0 \\
\hline C.pelliculosa (4) & 4 & 0 & 0 & 0 & 4 & 4 & 0 & 4 & 0 \\
\hline C.parapsilosis (3) & 3 & 0 & 3 & 0 & 0 & 3 & 0 & 3 & 0 \\
\hline C.krusei (2) & 2 & 0 & 0 & 2 & 0 & 2 & 0 & 2 & 0 \\
\hline Total & 24 & 0 & 11 & 2 & 11 & 24 & 0 & 24 & 0 \\
\hline
\end{tabular}

tection of MIC breakpoint values, and further classified into one of the following categories: susceptible (S), susceptible dose-dependent (S-DD) and resistant isolates (R).

\section{Discussion}

Candida species are cosmopolitan fungi that cause superficial and invasive diseases in humans (Fisher et al., 2011). In this study, specimens from patients with increased risk for fungal infections with Candida species were analysed. Specimens from these patients were classified into four groups: group I - patients with primary immune deficiency (HIV/ADIS, neutropenia, haematological diseases), group II - patients with prolonged hospital stay in ICU receiving antibacterial treatment with broad spectrum antibiotics, group III - patients with mucosal candidiasis only, and group IV - cystic fibrosis patients, with the aim to present the distribution and frequency of different Candida species in primarily non-sterile and sterile specimens, to determine the rate of candidemia in all four groups, and to determine the antifungal susceptibility profile of invasive isolates of Candida species towards the most frequently used antifungal agents in clinical practice. A total of 115 isolates of different Candida species were confirmed in different specimens (91 strains of Candida species from primarily non-sterile specimens with normal microflora, and 24 isolates of Candida species from blood) from patients with increased risk for fungal infections. The most frequent colonizer in the group I (with primary immune deficiency) was C. albicans, followed by C. tropicalis and C. glabrata. In specimens of the IInd group (with prolonged stay in ICU and receiving antibacterial treatment with broad spectrum antibiotics), again, the most frequent colonizer was $C$. albicans, followed by C. parapsilosis and C. glabrata. C. albicans was the most prevalent species in sputum, mouth swab, and urine, followed by $C$. glabrata, C. tropicalis and C. parapsilosis.
C. glabrata was most frequently confirmed in urine, followed by sputum and mouth swab. These results are consistent with literature data which show that $C$. albicans is still the most frequently isolated yeast from the respiratory tract in patients with primary immune deficiency and patients with prolonged hospital stay in ICU receiving combined antibacterial treatment with broad spectrum antibiotics. C. glabrata is the most frequent cause of candiduria (Fisher et al., 2011; Shin et al., 2010). Candiduria is rarely present in healthy individuals, but can be usually seen in hospitalized patients, especially in ICUs, where many predisposing factors contribute to higher rate of colonization with yeasts and increased risk for invasive fungal infections with Candida species. These predisposing factors are structural abnormalities of kidneys, diabetes mellitus, implanted urinary tract catheters, immunosuppression, and prolonged antibacterial treatment with broad spectrum antibiotics (Trofa et al., 2008). Studies from Brazil have shown that the three most prevalent isolates from urine in hospitalized patients were C. albicans (35.5 - $70 \%), C$. tropicalis (4.6 - 52.5\%) and C. glabrata (7 - 8.8 \%) (Binelli et al., 2006; Furlaneto et al., 2009). The study of Shin et al. (Shin et al., 2010) showed a rate of isolation of Candida spp. with $30.1 \%$ in sputum, $25.0 \%$ in urine, $15.8 \%$ in blood and $13.5 \%$ in urinary catheter. In our study, the most frequent colonizer of the respiratory mucosa in patients with cystic fibrosis was C. albicans (57\%), followed by C. dubliniensis $(6.7 \%)$, C. glabrata $(6.7 \%)$, C. parapsilosis (6.7\%), C. kefyr (6.7\%), and one isolate each of $C$. tropicalis, C. krusei, C. rugosa and C. pelliculosa. Except yeasts, in specimens from the respiratory tract of our patients with cystic fibrosis, bacterial isolates were also detected, most often P. aeruginosa (30\%), MRSA (13.3\%), S. maltophilia $(6.7 \%)$, and $3.3 \%$ each of $H$. influenzae, Flavobacterium species and Burkholderia cepacia. In the study of Noni et al. (2011) in 54 patients out of the total 121 investigated participants in the study (44.6\%), a chronic colonization with Candida species was registered (Noni et 
al., 2015). According to Noni et al. (2011) chronic colonization with C. albicans probably was associated with the duration of inhaled antibiotic treatment. Only one patient in our study had candidemia, and presented with positive blood culture with C. albicans.

The highest number of cases with candidemia in our study, in the $\mathrm{I}^{\mathrm{st}}$ group, were caused by $C$. tropicalis and C. krusei, followed by C. albicans, C. parapsilosis and C. tropicalis, in the II ${ }^{\text {nd }}$ group, C. albicans and C. pelliculo$s a$ were equally present, and were followed by $C$. parapsilosis and C. glabrata. In the III ${ }^{\text {rd }}$ group, 3 cases of candidemia were confirmed with positive blood cultures (one case with C. albicans, C. glabrata in 2 cases). Although C. albicans is still considered the most frequent etiological agent of candidemia, in the recent few decades, a significant increase of candidemia cases caused by other, nonalbicans Candida species (13) has been registered, and they are usually less susceptible to antifungal drugs. Data from the registry for candidemia in USA present the distribution of species: C. albicans (42\%), C. glabrata (27\%), C. parapsilosis (16\%), C. tropicalis (9\%), C. krusei (3\%), with non-albicans Candida species that account for 58\% from the total percentage of all candidemias. In studies in Europe, $49-53 \%$ of candidemias were caused by C. albicans, followed by C. parapsilosis (11-21\%), C. glabrata (10-12\%), C. tropicalis (6-11\%), C. krusei (1-9\%) and some other species, like C. dubliniensis, C. guilliermondii, C. kefyr, C. lusitaniae and C. rugosa (1-10\%) (Bassetti et al., 2006; Marchetti et al., 2004; Tortorano et al., 2004; Luzzati et al., 2000).

The biochemical identification and differentiation of invasive isolates of Candida species and their antifungal susceptibility testing is very important due to the rising numbers of immunocompromised patients across the globe (Arendrup, 2013). The information about the MIC values of different antifungal agents for each invasive isolate from blood and other primarily sterile specimens is of a great importance for treatment of invasive fungal infections caused by Candida species (Cuenca-Estrella et al., 2010). In general, identification of species could predict the antifungal susceptibility profile to antifungal agents. It is well known that $C$. albicans and $C$. parapsilosis are usually susceptible to all systemic antifungal agents; $C$. glabrata is susceptible or susceptible dose-dependent (S-DD) to fluconazole, while $C$. krusei is considered inherently resistant to fluconazole. The latest issues of IDSA therapeutic guidelines (Pappas et al., 2016) suggest that antifungal susceptibility testing is desirable, especially for C. albicans, to fluconazole, in patients with persistent candidemia or disseminated infection. In non-albicans Candida species, like $C$. glabrata, C. krusei or C. parapsilosis in patients with invasive infection, antifungal susceptibility testing to systemic antifungal agents is very useful, especially in patients who were previously treated with azoles. Based on literature data and clinical experience, C. albicans and C. parapsi- losis are considered susceptible to amphotericin B (Pfaller et al., 2007), although there are some reports that describe development of resistance in some strains (Almirante et al., 2005). In our study, all isolates of C. albicans were susceptible to amphotericin B. C. glabrata is considered susceptible dose-dependent (S-DD), and this is applicable for both fluconazole and amphotericin B, although, in our study, all isolates of C. glabrata were susceptible to amphotericin B (Panackal et al., 2006). C. krusei is considered susceptible to amphotericin B, although few studies have published data for resistant strains. Susceptibility to amphotericin B in our study was registered in all isolates, both in $C$. krusei and all other non-albicans Candida species. The results from our study have shown that $8.3 \%$ of all isolates of Candida species demonstrated resistance to fluconazole (2 isolates of C. krusei). Since C. krusei is considered as inherently resistant to fluconazole, its MIC values should not be interpreted with the breakpoint values established by the CLSI (Pappas et al., 2016). In 46\% of our isolates of C. albicans, C. glabrata, C. tropicalis and C. pelliculosa, higher MIC values to fluconazole were registered; they were all susceptible dose-dependent (S-DD). Lower susceptibility to fluconazole was shown in the study of Barchiesi et al. (2005). Similar data are demonstrated in the study of Pfaller et al. (2010), in which C. tropicalis have demonstrated moderate degree of resistance to fluconazole. Increased resistance to fluconazole among isolates of $C$. tropicalis is described in the study of Tortorano et al. (2004). Previous studies from South America have shown low rate of antifungal resistance. Godoy et al. (Godoy et al., 2003) found that most isolates of Candida species are susceptible to all antifungal agents. In a Brazilian study with 200 cases of candidemia, despite the high rate of infections caused by non-albicans Candida species (60\%, most often C. tropicalis and C. parapsilosis), a resistance towards azoles was found only in $1.5 \%$ of the isolates. In the same study, 2 isolates of C. krusei and $11 \%$ isolates of C. glabrata have been resistant to fluconazole. The SENTRY study has shown a lower resistance towards azoles, in specimens from Canada and South America, compared to specimens from USA (Pfaller et al., 2011). Less frequent use of fluconazole probably explains the lower rate of resistance towards azoles in these studies. In our study, all invasive isolates of Candi$d a$ species have shown susceptibility to voriconazole and caspofungin. In the study of Dagi et al. (2016), all isolates of Candida species were sensitive to voriconazole and caspofungin, three isolates of $C$. kefyr were resistant to amphotericin $\mathrm{B}$, and only one isolate of $C$. glabrata was resistant to fluconazole. Increased incidence in candidemia caused by non-albicans Candida species could have important implications for prevention, treatment and outcome from these life-threatening conditions, in critically ill patients, and therefore, early detection of fungal pathogens is of a crucial importance. Our study confirms the findings from previous studies which demonstrate high prevalence of candidemia with non-albicans Candida species. 
Resistance towards fluconazole was found in $33.3 \%$ isolates of Candida species. Resistant isolates to amphotericin B, voriconazole and caspofungin were not confirmed in our study. In conclusion, it is necessary to provide continuous epidemiological surveillance in order to follow the dynamics of candidemia in our patients. Since the response to antifungal treatment and positive clinical outcome from invasive infections with Candida species depends on early etiological diagnosis and prompt antifungal agent, it is also important to determine the colonization rate with Candida species, especially in patients with increased risk for development of invasive infections. In vitro antifungal susceptibility testing of invasive isolates of Candida species to antifungal agents should be always performed, in order to make the best choice for an efficient antifungal treatment, and for surveillance of antifungal resistance.

\section{References}

Almirante, B., Rodríguez, D., Park, B.J., Cuenca-Estrella, M., Planes, A.M., Almela, M., Mensa, J., Sanchez, F., Ayats, J., Gimenez, M., Saballs, P., Fridkin, S.K., Morgan, J., Rodriguez-Tudela, J.L., Warnock, D.W., Pahissa, A., 2005. Barcelona Candidemia Project Study Group. Epidemiology and predictors of mortality in cases of Candida bloodstream infection: results from population-based surveillance, Barcelona, Spain, from 2002 to 2003. J. Clin. Microbiol. 43(4), 1829-1835.

Arendrup, M.C., 2013. Candida and candidaemia. Susceptibility and epidemiology. Dan. Med. J. 60(11), B4698.

Barchiesi, F., Tortorano, A.M., Di Francesco, L.F., Rigoni, A., Giacometti, A., Spreghini, E., Scalise, G.,Viviani, M.A., 2005. Genotypic variation and antifungal susceptibilities of Candida pelliculosa clinical isolates. J. Med. Microbiol. 54(Pt 3), 279-285.

Bassetti, M., Righi, E., Costa, A., Fasce, R., Molinari, M.P., Rosso, R., Pallavicini, F.B., Viscoli, C., 2006. Epidemiological trends in nosocomial candidemia in intensive care. BMC Infect Dis. 10, 6-21.

Ben-Ami, R., Lewis, R.E., Kontoyiannis, D.P., 2009.Invasive mould infections in the setting of hematopoietic cell transplantation: current trends and new challenges. Curr. Opin. Infect. Dis. 22(4), 376-384.

Binelli, C.A., Moretti, M.L., Assis, R.S., Sauaia, N., Menezes, P.R., Ribeiro, E., Geiger, D.C., Mikami, Y., Miyaji, M., Oliveira, M.S., Barone, A.A., Levin, A.S., 2006. Investigation of the possible association between nosocomial candiduria and candidaemia. Clin. Microbiol. Infect. 12(6), 538-543.

Cuenca-Estrella, M., Gomez-Lopez, A., Alastruey-Izquierdo, A., Bernal-Martinez, L., Cuesta, I., Buitrago, M.J., RodriguezTudela, J.L., 2010. Comparison of the Vitek 2 Antifungal Susceptibility System with the Clinical and Laboratory Standards Institute (CLSI) and European Committee on Antimicrobial Susceptibility Testing (EUCAST) Broth Microdilution Reference Methods and with the Sensititre YeastOne and Etest Techniques for In Vitro Detection of Antifungal Resistance in Yeast Isolates. J. Clin. Microbiol. 48(5), 1782-1786.

Dagi, H.T., Findik, D., Senkeles, C., Arslan U., 2016. Identification and antifungal susceptibility of Candida species isolated from bloodstream infections in Konya, Turkey. Ann. Clin. Microbiol. Antimicrob. 15(1), 36.

Fisher, J.F., Sobel, J.D., Kauffman, C.A., Newman, C.A., 2011. Candida urinary tract infections-treatment. 52(6), S457-466.

Furlaneto, M.C., Rota, J.F., Quesada, R.M., Furlaneto-Maia, L., Rodrigues, R., Oda, S., Oliveira, M.T., Serpa, R., França, E.J., 2011. Species distribution and in vitro fluconazole susceptibility of clinical Candida isolates in a Brazilian tertiary-care hospital over a 3-year period. Rev. Soc. Bras. Med. Trop. 44(5), 595-599.

Girmenia, C., Finolezzi, E., Federico, V., Santopietro, M., Perrone, S., 2011. Invasive Candida infections in patients with haematological malignancies and hematopoietic stem cell transplant recipients: current epidemiology and therapeutic options. Mediterr. J. Hematol. Infect. Dis. 3(1), e2011013.

Godoy, P., Tiraboschi, I.N., Severo, L.C., Bustamante, B., Calvo, B., Almeida, L.P., da Matta, D.A., Colombo, A.L., 2003. Species distribution and antifungal susceptibility profile of Candida spp. bloodstream isolates from Latin American hospitals. Mem. Inst. Oswaldo. Cruz. 98(3), 401-405.

Luzzati, R., Amalfitano, G., Lazzarini, L., Soldani, F., Bellino, S., Solbiati, M., Danzi, M.C., Vento, S., Todeschini, G., Vivenza, C., Concia, E., 2000. Nosocomial candidemia in non-neutropenic patients at an Italian tertiary care hospital. Eur. J. Clin. Microbiol. Infect. Dis. 19(8), 602-607.

Luzzati, R., Allegranzi, B., Antozzi, L., Masala, L.,Pegoraro, E., Azzini, A., Concia, E., 2005. Secular trends in nosocomial candidaemia in non-neutropenic patients in an Italian tertiary hospital. Clin. Microbiol. Infect. 11(11), 908-913.

Marchetti, O., Bille, J., Fluckiger, U., Eggimann, P., Ruef, C., Garbino, J., Calandra, T., Glauser, M.P., Täuber, M.G., Pittet, D., 2004. Fungal Infection Network of Switzerland. Epidemiology of candidemia in Swiss tertiary care hospitals: secular trends, 1991-2000. Clin. Infect. Dis. 38(3), 311-320.

Meyer, E., Geffers, C., Gastmeier, P., Schwab, F., 2013. No increase in primary nosocomial candidemia in 682 German intensive care units during 2006 to 2011. Eurosurveillance, 18(24).

Mirchevska, G., 2011. Evaluation of methods for antifungal susceptibility testing of Candida species to antifungal agents. Master thesis. Faculty of Medicine, University "Ss. Cyril and Methodius", Republic of Macedonia

Montagna, M.T., Caggiano, G., Lovero, G., De Giglio, O., Coretti, C., Cuna, T., Iatta, R., Giglio, M., Dalfino, L., Bruno, F., Puntillo F., 2013. Epidemiology of invasive fungal infections in the intensive care unit: results of a multicenter Italian survey (AURORA Project). Infection, 41(3), 645-653.

Morgan, J., Meltzer, M.I., Plikaytis, B.D., et al.,2005. Excess mortality, hospital stay, and cost due to candidemia: a casecontrol study using data from population-based candidemia surveillance. Infect. Control. Hosp. Epidemiol. 26, 540-547.

Noni, M., Katelari, A., Kaditis, A., Theochari, I., Lympari, I., Alexandrou-Athanassoulis, H., Doudounakis, S.E., Dimopoulos, G., 2015. Candida albicans chronic colonisation in cystic fibrosis may be associated with inhaled antibiotics. Mycoses. 58(7), 416-421.

Panackal, A.A., Gribskov, J.L., Staab, J.F., Kirby, K.A., Rinaldi, M., Marr, K.A., 2006. Clinical Significance of Azole Antifungal Drug Cross-Resistance in Candida glabrata. J. Clin. Microbiol. 44, 1740-1743.

Pappas, P.G., Kauffman, C.A., Andes, D.R., Clancy, C.J., Marr, K.A., Ostrosky-Zeichner, L., Reboli, A.C., Schuster, M.G., 
Vazquez, J.A., Walsh, T.J., Zaoutis, T.E., Sobel, J.D., 2016. Clinical Practice Guideline for the Management of Candidiasis.2016 Update by the Infectious Diseases Society of America. Clin. Infect. Dis. 62(4), e1-50.

Pfaller, M.A., Diekema, D.J., Gibbs, D.L., Newell, V.A., Ellis, D., Tullio, V., Rodloff, A., Fu, W., Ling, T.A. and the Global Antifungal Surveillance Group Results from the ARTEMIS DISK Global Antifungal Surveillance Study, 1997 to 2007, 2010. A 10.5-Year analysis of susceptibilities of Candida species to fluconazole and voriconazole as determined by CLSI standardized disk diffusion. J. Clin. Microbiol. 48(4), 1366-1377.

Pfaller, M.A., Diekema, D.J., 2007. Epidemiology of invasive candidiasis: a persistent public health problem. Clin. Microbiol. Rev. 20, 133-163.

Pfaller, M.A., Diekema, D.J., Gibbs, D.L., Newell, V.A., Ellis, D., Tullio, V., Rodloff, A., Fu, W., Ling, T.A., 2010. Global Antifungal Surveillance Group.Results from the ARTEMIS DISK Global Antifungal Surveillance Study, 1997 to 2007: a 10.5-year analysis of susceptibilities of Candida species to fluconazole and voriconazole as determined by CLSI standardized disk diffusion. J. Clin. Microbiol, 48(4), 13661377.

Pfaller, M.A., Messer, S.A., Moet, G.J., Jones, R.N., Castanheira, M., 2011. Candida bloodstream infections: comparison of species distribution and resistance to echinocandin and azole antifungal agents in Intensive Care Unit (ICU) and non-ICU settings in the SENTRY Antimicrobial Surveillance Program (2008-2009). Int. J. Antimicrob. Agents 38(1), 65-69.

Prowle, J.R., Echeverri, J.E., Ligabo, E.V., Sherry, N., Taori, G.C., Crozier, T.M., Hart, G.K., Korman, T.M., Mayall, B.C., Johnson, P.R., Bellomo, R., 2011. Acquired bloodstream infection in the intensive care unit: incidence and attributable mortality. Crit. Care. 15(2), R100.

Quenot, J.P., Binquet, C., Kara, F., Martinet, O., Ganster, F., Navellou, J.C., Castelain, V., Barraud, D., Cousson, J., Louis, G., Perez, P., Kuteifan, K., Noirot, A., Badie, J., Mezher, C., Lessire, H., Pavon, A., 2013. The epidemiology of septic shock in French intensive care units: the prospective multicenter cohort EPISS study. Crit. Care 17(2), R65.

Shin, H.S., Park, Y.B., Shin, D.S., 2010. Isolation frequency of Candida species from clinical specimens. Kor. J. Mycol. 38, 146-151.

Tortorano, A.M., Peman, J., Bernhardt, H., Klingspor, L., Kibbler, C.C., Faure, O., Biraghi, E., Canton, E., Zimmermann, K., Seaton, S., Grillot, R., 2004. ECMM Working Group on Candidaemia. Epidemiology of candidaemia in Europe: results of 28-month European Confederation of Medical Mycology (ECMM) hospital-based surveillance study. Eur. J. Clin. Microbiol. Infect. Dis. 23, 317-322.

Trofa, D., Gácser, A., Nosanchuk, J.D., 2008. Candida parapsilosis, an emerging fungal pathogen. Clin. Microbiol. Rev. 21(4), 606-625.

Wisplinghoff, H., Bischoff, T., Tallent, S.M., Seifert, H., Wenzel, R.P., Edmond, M.B., 2004. Nosocomial bloodstream infections in US hospitals: analysis of 24179 cases from a prospective nationwide surveillance study. Clin. Infect. Dis. 39(3), 309-317.

Zaoutis, T,E., Argon, J., Chu, J., Berlin, J.A., Walsh, T.J., Feudtner, C., 2005. The epidemiology and attributable outcomes of candidemia in adults and children hospitalized in the United States: a propensity analysis. Clin. Infect. Dis. 41, 1232-1239.

\title{
Дистрибуција и антифунгална осетливост на Candida species кај пациенти со зголемен ризик за фунгални инфекции
}

\author{
Гордана Мирчевска, Маја Јурхар-Павлова, Весна Котевска, Елена Трајковска- \\ Докиќ, Жаклина Цековска, Гордана Јанкоска, Милена Петровска, Никола \\ Пановски
}

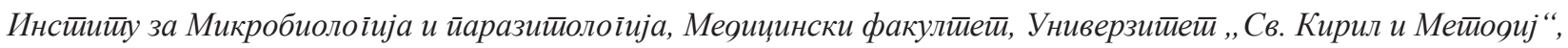
Ул.50 Дивизија број 6, 1000, Скойје, Рейублика Макеоонија
\end{abstract}

Клучни зборови: Candida species, антифунгални агенси, фунгални инфекции, Е-тест

Candida species ce опортунистички квасници, кои можат да бидат сериозна закана за имунокомпромитираните и критично болните лица, и се причина за зголемен морбидитет и морталитет кај хоспитализирани пациенти. Целта на оваа студија беше да се определи фреквенцијата и дистрибуцијата на различни видови Candida species во клинички примероци од лица со ризик за развој на фунгални инфекции, и да се определи профилот на осетливост на инвазивните 
изолати на Candida species кон антифунгални агенси. Во тек на двегодишен период, клинички примероци од 120 пациенти, поделени во 4 групи, беа анализирани на Институтот за Микробиологија и паразитологија во Скопје, Медицински факултет, Скопје, Македонија. Секоја група се состоеше од примероци од 30 пациенти, со примарен имун дефицит, критично болни пациенти лекувани во единици за интензивно лекување (ЕИЛ), пациенти со мукозна кандидијаза и пациенти со цистична фиброза. Сите примероци беа испитувани со конвенционални миколошки методи. Идентификацијата на Candida species се изведуваше со VITEK-2 систем (bioMérieux, France). Е-тест стрипови на флуконазол, вориконазол, амфотерицин Б и каспофунгин (АВ bioMerieux, France) се користеа за испитување на профилот на осетливост на инвазивните изолати на Candida species. Во оваа студија, беа изолирани 115 соеви на Candida species од различни клинички примероци (91 изолати од мукозни површини и 24 изолати од крв). Колонизација на мукозните површини на гастроинтестиналниот, респираторниот и уринарниот тракт беше регистрирана кај $56,67 \%$ $(17 / 30), 56,67 \%(17 / 30), 90 \%(27 / 30)$ и 100\% (30/30) примероци од првата и втората група, третата група, четвртата група, соодветно. Во сите четири групи на пациенти, беа докажани следните специеси: C. albicans - 55\%, C. glabrata - 17,6\%, C. parapsilosis - 7,7\%, C. tropicalis - 6,6\%, неидентификувани C. species - 4,4\%, C. dubliniensis - 3,3\%, C. kefyr - 2,2\%, и по еден изолат од C. rugosa, C. pelliculosa и C. krusei. Позитивна хемокултура беше регистрирана кај $23,33 \%$ примероци од првата група, $43,33 \%$ од втората група, $23,08 \%$ од третата група, и кај еден примерок со цистична фиброза. Најчести изолати од хемокултура во првата група беа C. tropicalis и C. krusei, следени од C. albicans, C. parapsilosis и C. tropicalis, а во втората група подеднакво застапени беа C. albicans и C. pelliculosa, следени од C. parapsilosis и C. glabrata. Сите инвазивни изолати на Candida species беа осетливи на амфотерицин Б, вориконазол и каспофунгин. Резистенција кон флуконазол беше регистрирана кај 8,3\% (2/24) од соевите на Candida species $(C$. krusei). Осетливост во зависност од дозата кон флуконазол беше докажана кај 46\% (11/24) од инвазивните изолати. Нашата студија ја потврдува високата преваленција на колонизација и кандидемија co non-albicans Candida species. Резистенција кон антифунгални агенси беше најдена само кај два изолати на $C$. krusei. Неопходно е епидемиолошко следење на динамиката на кандидемијата и одредување на профилот на осетливост на инвазивните изолати на Candida species кај нашите пациенти. 